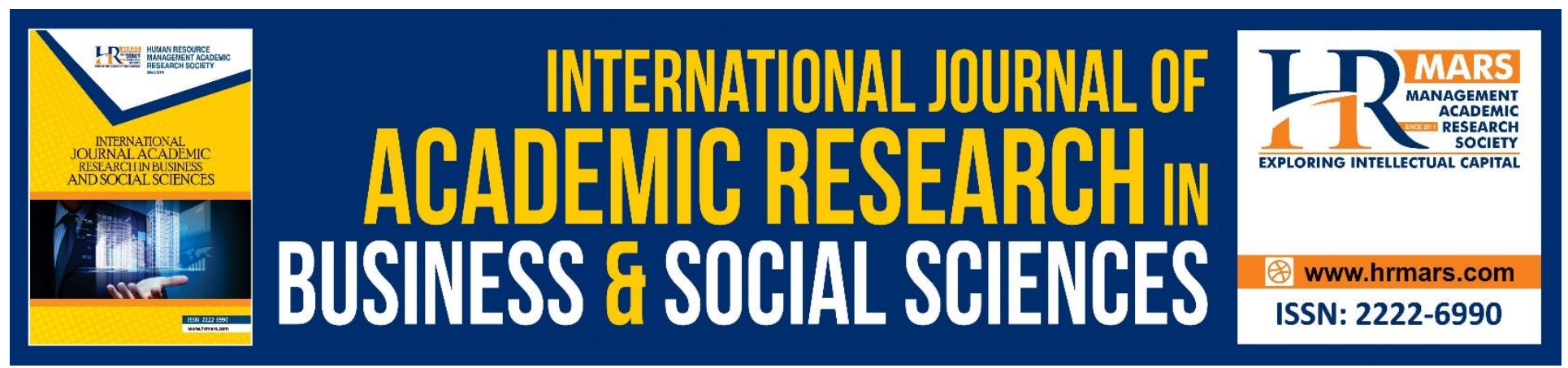

\title{
Garis-Garis Pelangi Musical Theatre: A Research on the Implementation of Moral Values Through the Concept of Jukebox Musical Performance
}

Muhammad Faisal Ahmad, Zolkipli Abdullah, Syarul Azlina

To Link this Article: http://dx.doi.org/10.6007/IJARBSS/v10-i11/8102

DOI:10.6007/IJARBSS/v10-i11/8102

Received: 02 September 2020, Revised: 26 September 2020, Accepted: 18 October 2020

Published Online: 20 November 2020

In-Text Citation: (Ahmad, Abdullah, \& Azlina, 2020)

To Cite this Article: Ahmad, M. F., Abdullah, Z., \& Azlina, S. (2020). Garis-Garis Pelangi Musical Theatre: A Research on the Implementation of Moral Values Through the Concept of Jukebox Musical Performance. International Journal of Academic Research in Business and Social Sciences. 10(11), 414-425.

\section{Copyright: (c) 2020 The Author(s)}

Published by Human Resource Management Academic Research Society (www.hrmars.com)

This article is published under the Creative Commons Attribution (CC BY 4.0) license. Anyone may reproduce, distribute, translate and create derivative works of this article (for both commercial and non-commercial purposes), subject to full attribution to the original publication and authors. The full terms of this license may be seen

at: http://creativecommons.org/licences/by/4.0/legalcode

Vol. 10, No. 11, 2020, Pg. 414 - 425

http://hrmars.com/index.php/pages/detail/IJARBSS

JOURNAL HOMEPAGE

Full Terms \& Conditions of access and use can be found at http://hrmars.com/index.php/pages/detail/publication-ethics 


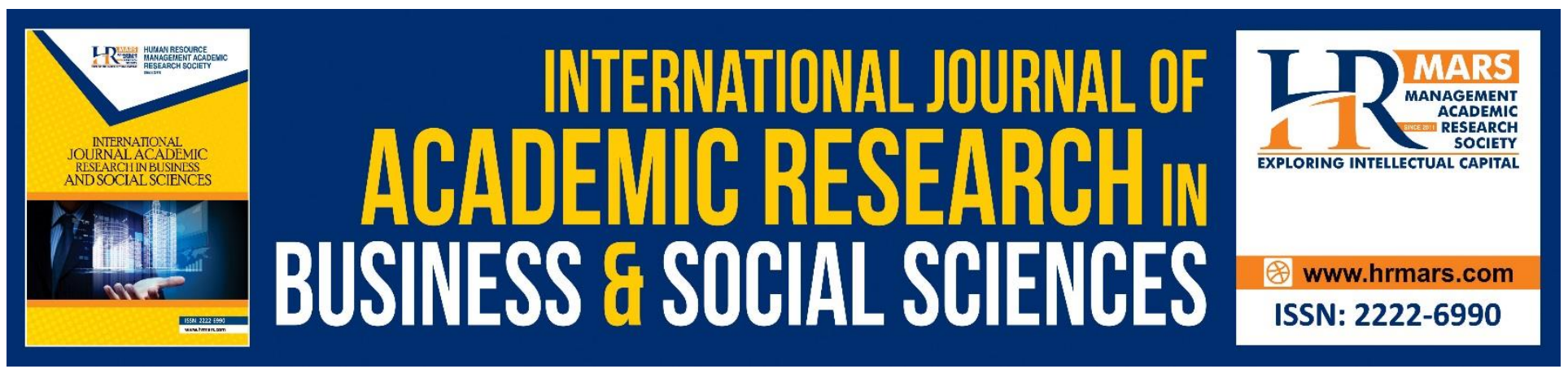

\title{
Garis-Garis Pelangi Musical Theatre: A Research on the Implementation of Moral Values Through the Concept of Jukebox Musical Performance
}

\author{
Muhammad Faisal Ahmad, Zolkipli Abdullah, Syarul Azlina \\ Faculty of Music and Performing Arts, Sultan Idris Education University, Malaysia
}

\begin{abstract}
Garis-Garis Pelangi (GGP) musical theatre is a musical theatre that revolves around the concept of jukebox musical. Jukebox musical performance lifts up popular recorded songs in forming a musical drama narrative. This research reveals the objective of implementing moral values in GGP through jukebox-style musical performance. Selecting the concept of jukebox musical is based on the ability of famous songs to attract and influence the audience. Therefore, it also engages and touches the audience to enjoy the story of friendship through the popular songs being played in the performance. Jukebox-style musical performance approach is based on the performance style that had flourished in the United States of America by means of producing films and theatres. Works like Jersey Boys, Mamma Mia, and Moulin Rouge are some examples that inspired the performance of GGP. Problem statement is tackled from the understanding within local artists in developing musical performances. Majority of the musicals performed did not follow through with specific concepts, prompting a confusion in the concept of musical and messages that failed to be conveyed. Thus, GGP was created and rich with moral values which became one of the main strengths of this work. Hence, the way the actors and actresses exress every message the moral values have to convey is the proof of in-depth understanding, delivery and appreciation. To further appreciate the moral values instilled, the expressions of the character applied by each actor and actress were analysed based on the dialogue deliverance through singing technique. This discussion can be a medium to cultivate moral values among the people following the demands of generations that are more easily influenced by performing arts.
\end{abstract}

Keyword: Musical Theatre, Moral Values, Jukebox Musical, Acting.

\section{Introduction}

The director of Rouge (2001): Lurhmann (2001) once stated that, "A jukebox musicals is an original stage musical not based on film that uses previously released popular songs that have no direct relation to the story as its musical score". The original idea of a work plays an important role in claiming jukebox musical as a concept in performances. Lurhmann also pointed out that the narrative aspect of a work needs to be something new and fresh, and the musical element is inserted with 
INTERNATIONAL JOURNAL OF ACADEMIC RESEARCH IN BUSINESS AND SOCIAL SCIENCES Vol. 10, No. 11, 2020, E-ISSN: 2222-6990 @ 2020 HRMARS

popular songs which are not specifically composed for said theatre. However, the song composition used in jukebox musicals needs to fit the storyline that is intended to be conveyed. Based on the aforementioned aspects, a jukebox-style musical entitled Garis-Garis Pelangi (GGP) was produced.

The script for the musical GGP was written by Faisal Ahmad in 2009. In general, this musical tells the story of three friends, three conflicts and three different worlds combined within the value of friendship. The friendship between Uda, Ayu and Sherry was established since they were in school. Their surroundings forced them to be separated for 8 years. The friendship which was deemed to be honest was proven wrong when the reunion involving the three friends hid their flaws and weaknesses. Despite that, the conflict and pressure from their surroundings caused the hypocrisy to be broken down in favour of the sincerity of the friendship.

This theatre highlighted the friendship theme conveyed in musical genre. Jukebox musical approach was implemented to strengthen the storyline with the use of the country's popular songs. The selection of songs was made based on the suitability of the plot and lyrics combined within a narrative heavily plotted with conflicts and the value of friendship. The concept of jukebox musical encourages the use of well-known songs that were recorded by local singers. Several songs that were inserted in the musical theatre Garis-garis Pelangi are Bimbang Terluka Lagi (Noor Kumalasari \& Sudirman), Aku Juga Manusia (Amir Jahari), Darah Muda (Saloma), Ceritaku Ceritamu (Fauziah Ahmad Daud), Sekian Lama (Siti Nurhaliza), and Joget Hati Senang (Adibah Noor). According to Charles D. Adamson (2013), the connection between previously recorded songs with acting is a good move in inspiring the actors and actresses to give their utmost performance since using the songs will deepen the connection between the characters and audience. Charles' opinion has proven that jukebox musical concept can be a contributing factor in engaging the performance to the audience.

\section{The Role of Dramatic Songs in the Jukebox Musical Garis-Garis Pelangi}

Aristotle had mentioned the key points to developing a method of deliverance are the main idea of what is to be said, styles or languages used by the speaker, the elaboration of the ideas and the ability of the speaker to verbalise words based on his or her memories (Cooper, 1960). In this context, the technique to delivering moral values is performed by verbalising the chosen lyrics through dialogues. The main idea contained in the lyrics is expressed with various methods of deliverance. According to Hamzah (2012):

"Values are defined as a concept made as a foundation by the community to see, measure or make decision on things, status, quality, behavioural status and thw quirks of individual or groups of people as good, precious and valuable."

The song Darah Muda sung by Sherry tells the story of a teenager's soul that is always wanting something without thinking of the consequences. Sherry is a night club singer who regrets her fate and follows her heart blindly. Even though the content of the song revolves around love, but the message intended to be conveyed is still referring to teenagers who are blindly passionate in relationships and need to always take care of themselves. Some of the lyrics from the song are as follows: 
INTERNATIONAL JOURNAL OF ACADEMIC RESEARCH IN BUSINESS AND SOCIAL SCIENCES

Vol. 10, No. 11, 2020, E-ISSN: 2222-6990 @ 2020 HRMARS

Hatiku rindu kepadamu

Tertawan sejak mula bertemu

Aku sangkakan bahagia

Cinta berbalas mesra

Tapi kanda buat lupa

Ku merana hati luka

Masa remaja darah muda

Banyak gelora mudah tergoda

Orang baru kanda temu

Kini lupakan daku..

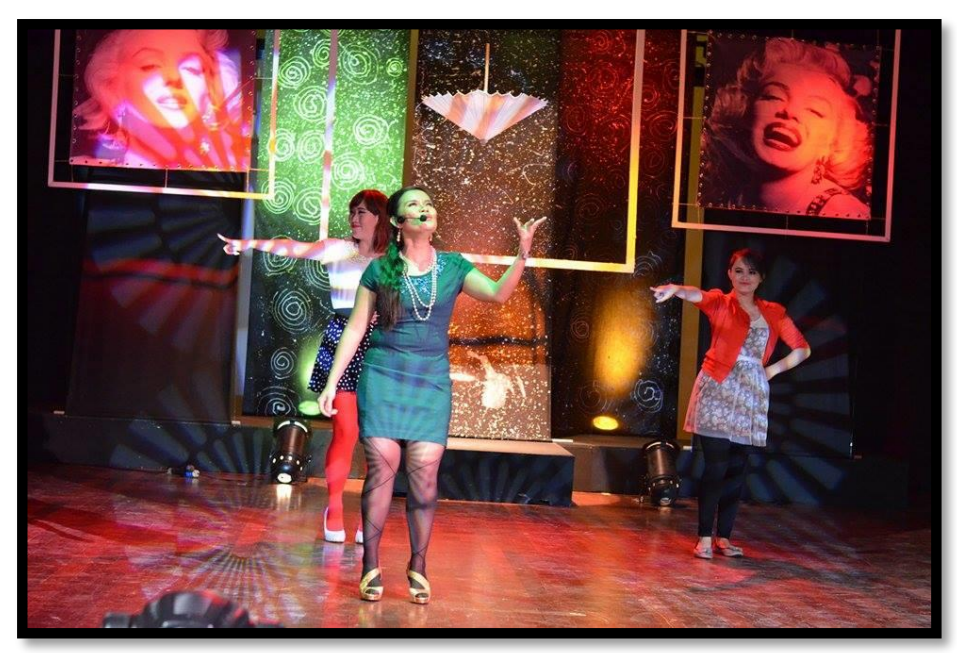

Photo 1: The song Darah Muda (originally sung by Saloma) performed by Sherry

Verbalised dialogue through the lyrics was delivered in a spontaneous way at the beginning of the song and then emphasis was given on certain words such as 'darah muda' and 'mudah tergoda' which will further clarify the meaning, cause and effect in the song.

The same method had also been implemented in other songs such as Ceritaku Ceritamu which was originally sung by Fauziah Ahmad Daud and performed by Mak Koyo. The method of dialogue deliverance brought emphasis on several aspects of adjustable languages, intonation and accurate speech style which fit the background of the situation contained within a storyline (Kimbrough, A. M., 2002). For instance, a situation in which a mother who is giving some advice to her children through a song. In the process of shaping the technique of a good dialogue deliverance, expression element is also indirectly involved since this gives practise for the actors and actresses to produce suitable utterances with the style and facial gestures. Some extracts from the song Ceritaku Ceritamu and the emphasised lyrics are as follows:

Oh inilah kisahnya manusia

Oh inilah kisahnya kehidupan 
INTERNATIONAL JOURNAL OF ACADEMIC RESEARCH IN BUSINESS AND SOCIAL SCIENCES

Vol. 10, No. 11, 2020, E-ISSN: $2222-6990$ @ 2020 HRMARS

\section{Ku terlihat senyuman dan tangisan \\ Ku terteringat ketawa dan jeritan \\ Inilah ceritaku \\ Dan jua ceritamu \\ Bersama ku mengejar bahgia oh di dunia..}

The message brought forward in this song definitely refers to an individual's experiences in life. The way this song being performed will be different if it is sung by a different character in a different situation. The message delivered in this song was performed by the character of an elderly woman called Mak Koyo to a youth named Uda. The moral values inserted in this song give more emphasis on the nostalgia of someone's experiences. The purpose of singing this song is to support and provide motivation to young adults who are fragile and give up easily when faced with challenges and obstacles in life. Using the background of the situation at a stall in a village had impacted the union between emotions and surroundings.

Dialogue deliverance technique implemented in songs is a method that can stimulate appreciation as how an actor or actress projects his or her dialogues. For an actor or actress, to obtain a better combination in his or her performance, the expression and emotion elements need to be properly aligned with the meaning behind the songs performed. Gary Faigin (2008) had written in his book about applying expression in acting. He mentioned that:

Any serious actor is recommended to learn and master these expressions through training all his/her face muscles effectively and recording him/ herself. The speed of how you can display them effectively, is a direct indication of your talent. Only a professional observer can judge your performance. Never be tricked into thinking yourself persuasive. Most people think they can do so but give rediculous results.

To deliver good facial expressions, skills and continuous practice need to be done so that character development can be seen more clearly. Dialogue utterances need to consider the intonation, reaction and action to be consistent. This means, every uttered word has to be relevant with the character deliverance during that time. Emphasis is put on high and low notes on the words uttered in a dynamic energy even though the dialogues demand sad or whispering emotion and reaction. 
INTERNATIONAL JOURNAL OF ACADEMIC RESEARCH IN BUSINESS AND SOCIAL SCIENCES Vol. 10, No. 11, 2020, E-ISSN: 2222-6990 @ 2020 HRMARS

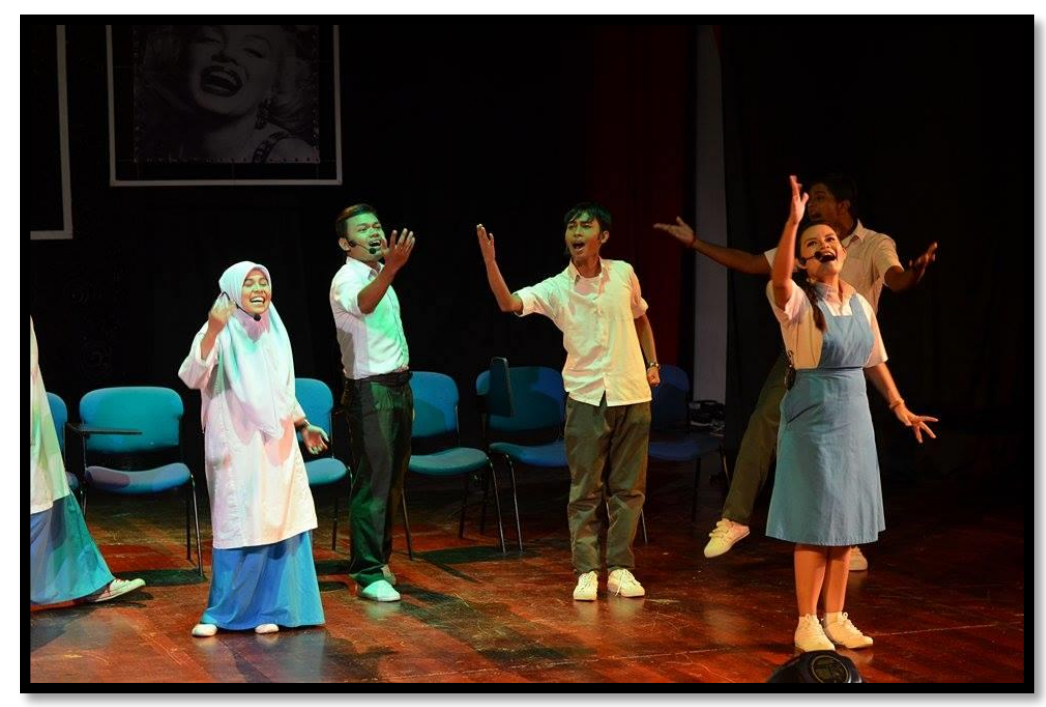

Photo 2: The singing of Horey Horey strengthened the emphasis on the message being delivered

\section{The Message of the Song Joget Hati Senang in the Musical Theatre Garis-Garis Pelangi}

The effectiveness of the style of dialogue utterances in GGP had widely contributed to the quality in character deliverance through several basic aspects such as producing suitable variations, dynamics and projection, consistent dialogue utterances between the characters and emotions. By referring to jukebox musical concept, it has more or less helped the actors and actresses in the process of memorising the melody and lyrics most songs inserted in the musical are the songs which are famous among locals.

The moral values conveyed through certain songs and characters need more appreciation compared to the dialogues uttered without singing. Suitable selection of songs also plays an important role because the songs need to be fitting with the scenes that are being performed. The song Joget Hati Senang (originally sung by Adibah Noor) which was performed by all characters contains very clear message on moral values. Basically, the song was divided into several parts and performed by different characters. The lyrics of Joget Hati Senang performed by different characters are as shown below:

WAWA

Dik janganlah di makan pujian orang

Takut nanti tersungkur tak sedar diri

Biar apa di kata orang

Baju mesti diukur di badan sendiri

MAK KOYO

Mungkin juga senyumku tidak semanis

Potonganku juga mungkin tak secantik

Biar apa dikata orang

Rezeki dah tentu anugerah Illahi 
INTERNATIONAL JOURNAL OF ACADEMIC RESEARCH IN BUSINESS AND SOCIAL SCIENCES

Vol. 10, No. 11, 2020, E-ISSN: 2222-6990 @ 2020 HRMARS

EIRA

Bukan ku minta simpati

Tak mahu dikasihani

Ku memang senang begini

Terserah saja pada Illahi

The lyrics in Joget Hati Senang clearly dispalys the message in the element of giving advice. The deliverance of the song was distributed according to the characters since each character conveyed different messages. For instance, the first verse was sung by Wawa who was a boutique owner with a confident and open-minded demeanor. Wawa sung the first verse which was specifically directed towards Eira, a teenage girl who had just returned from the overseas. The advice given was to always be humble and mindful so that she would not be easily influenced with praises. The verse was directed towards Eira since Eira was going to work with Wawa.

The second verse was sung by Mak Koyo for Pak Zaini (the husband of Mak Koyo). Fitting with her character as an elderly lady, Mak Koyo conveyed the message to her husband, reminding him to always be grateful with everything that they had. The humbleness in Mak Koyo also served as a reminder for herself and her husband. Next is the third verse performed by Ayu towards Eira. Ayu delivered the message of her happiness when her younger sister, Eira was offered a job. The advice given in the particular verse is the hope that her sister became someone who is resilient in living the life of her new job. The advice given by Ayu was answered by Eira in the next verse. All advice given by Wawa and Ayu was reciprocated by the lyrics which mentioned that she did not ask for sympathy, insisting that every obstacle and challenge coming her way were tests given by The Almighty. The combination of different characters in a song in which was originally performed by only one singer had hugely impacted the union of various messages within a storyline. The moral values instilled had clearly illustrated the harmony among the people in reminding each other. It had also portrayed the culture of a community who always cared for each other and the existence of intact family relationships. 


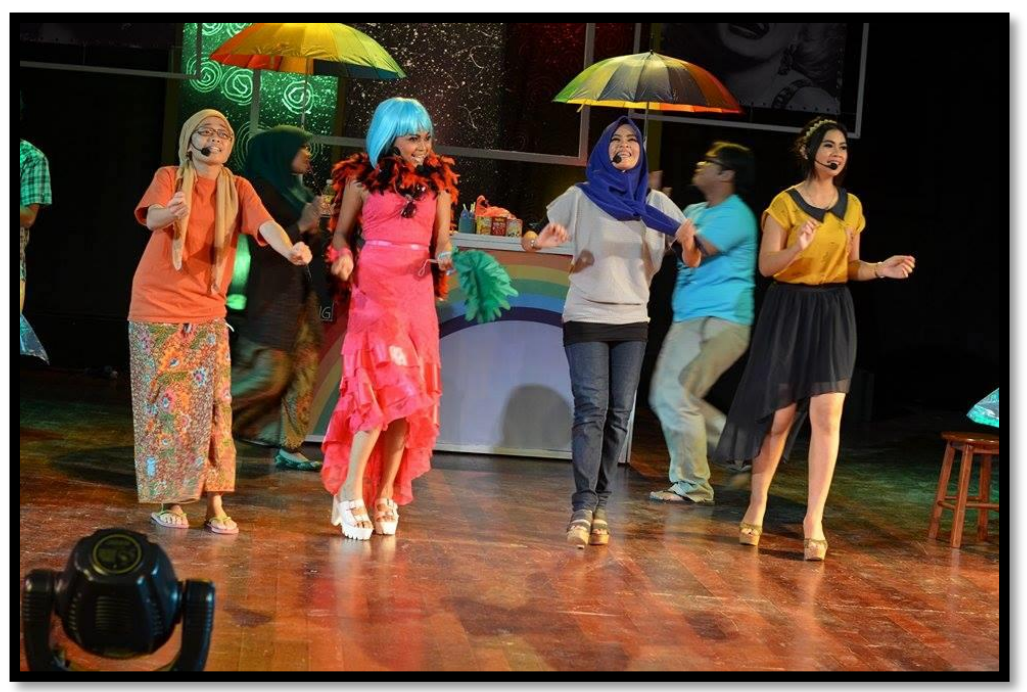

Photo 3: The scene from Joget Hati Senang. From the left; Mak Koyo, Wawa, Ayu and Eira.

\section{The Value of Friendship in the Musical Theatre Garis-Garis Pelangi}

In general, the value of friendship refers to the human behaviour from the behavioural aspect between two or more people. According to Rubin (2004), friendship is multi-dimensional in attribution and indulging human in various ways (such as wealth, hopes, fears and others). Meanwhile, Bryne \& Baron (2008) mentioned that it is a relationship in which two people spend their time together, interacting in mutliple occasions, and providing emotional support.

Henry (1975) defines value as something precious and valuable such as love, kindness, fun, satisfaction, honesty, modesty, politeness and peace. Meanwhile, the value of friendship can be summarised as as a close relationship between two or more people, putting some sort of sincerity that appreciates the established relationship.

In the context of friendship values in GGP, it is evidently highlighted through the main theme of the theatre, which is friendship. The friendship between Ayu, Uda and Sherry is a type of friendship that holds high moral values since it does not only display the sincerity of the friendship, but also connects the cause and effect from the untrusworthy feeling that resides deep within them. Based on the friendship theme, this research also relates the concept of friendship theory which was introduced by Selmen (1990) who categorised the three levels of friendship, which are Level One, Level Two, and Level Three.

- Level One - happens to children in pre-school or kindergarten. Usually, their friends consist of their neighbours' children, playmates and others. In this level, they cannot evaluate the value of friendship. They only think of having fun and their own satisfaction.

- Level Two - happens to children between ages 8 to 10. Friends become their trusted companions. Selmen called it as 'one way assistance' in which they confide in their friends when they need help. 
- Level Three - happens when they are adolescents. In this level, they start to appreciate the value of friendship. Selmen also called it as'intimate and mutually shared relationship'. Trust and sensitivity start to be instilled in the friendship.
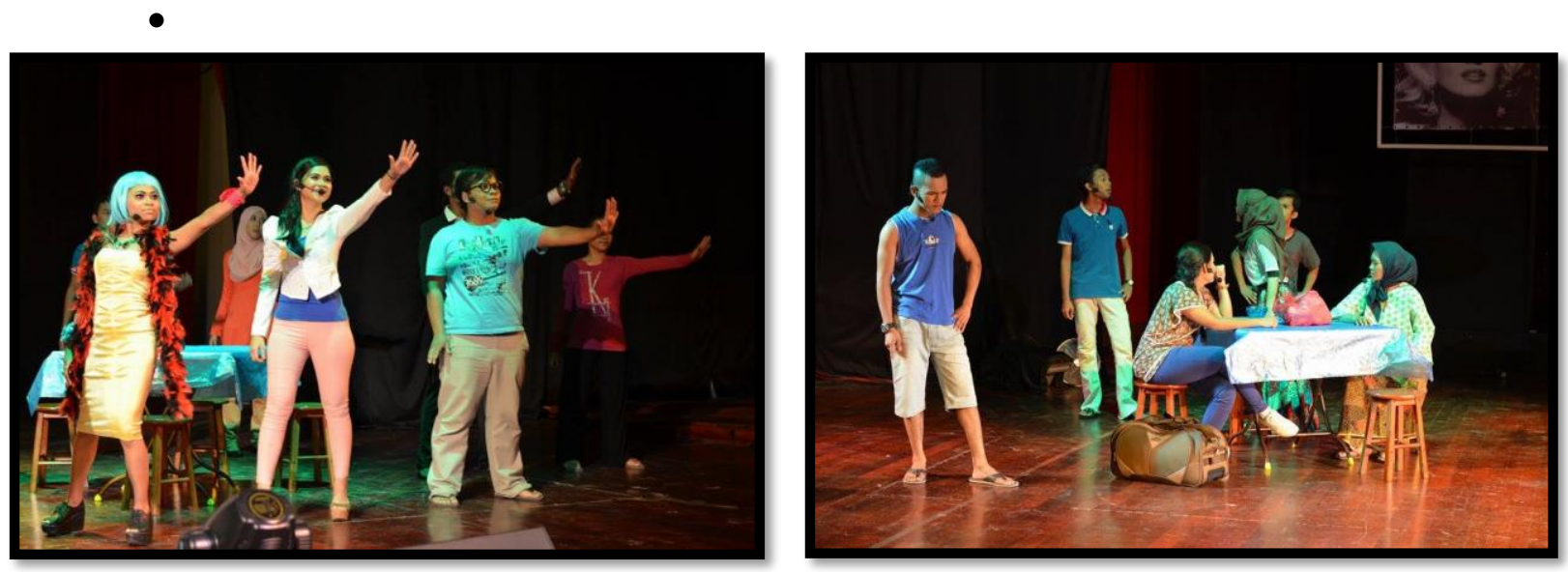

Photo 4: Several scenes performed in the musical theatre Garis-Garis Pelangi

Based on the three levels introduced by Selmen, it is evident that the value of friendship portrayed in GGP had advanced to the third level. It was proven with the scene of the end of school term, followed by the transition to adulthood. To further strengthen the theme of friendship, the author had inserted some words of wisdom to illustrate the beauty of that friendship. The words are as follows:

"A friendship is like a box of crayons. Each of them has different colours. However, when they are mixed on a piece of paper, a beautiful rainbow is formed!"

Throughout the whole performance, these words were repeated thrice to further emphasise the value of friendship. The first time the words were uttered is at the beginning of the performance and became the show starter. The first utterance was spoken using a background voice. The second time the words were spoken, they were verbalised by the character Ayu at the end of their school term. This scene revealed the promise made by the three teenagers to remain friends. The third and the last time it was mentioned, they used a background voice during climax in which Uda started to lose the trust he had towards his friends when Ayu came clean about her broken marriage and also when Sherry was sick and she kept her illness a secret, but the secret started to slowly be uncovered. The third time the words were uttered served the purpose to remind the three adults about the promise they made about their friendship all those years ago.

In the words, friendship is illustrated as a box of crayons. The use of simile (crayons) in friendships is related to M. Woodhead (2005) who mentioned the crayons as 'colour of life, friendship \& childhood'. The value of friendship in this theatre can be seen through three groups of friends:

- Protagonist Group - Ayu, Uda, Sherry

- Antagonist Group - Nizam, Shafieq, Putet

- Supporting Role Group - Aziz, Ruben, Shishi 
The protagonist group which consists of Ayu, Uda and Sherry is a group which is the main focus of the story. The value of friendship was brought forward based on their friendship. These three characters evolved the story from their friendship to the point where conflict and climax arose among them. The friendship that was established during their school years had strengthened their relationship and put trust as a very prominent value in a friendship. However, temporary separation, the change of time as well as external and internal factors caused the friendship to fade away in the belief of not wanting to be looked down upon by their own friends. Each character had to deal with their own conflicts, causing them to be hypocrites so that they would always be admired.

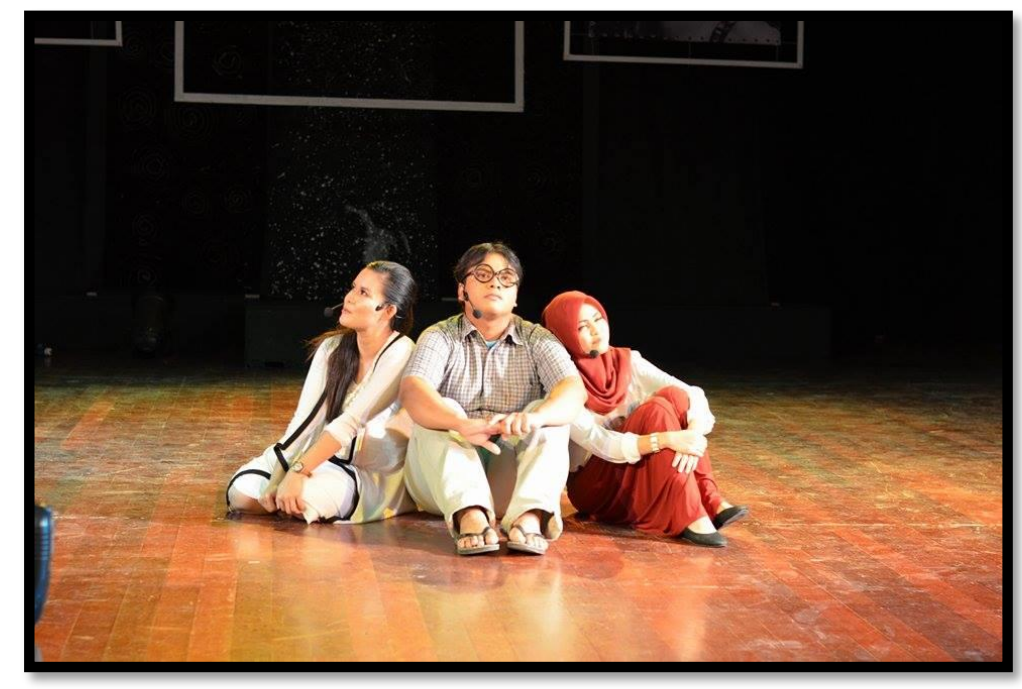

Photo 5: The protagonist group which consist of Sherry (left), Uda (middle), and Ayu (right)

The meeting of these three friends after eight years had risen conflicts which caused them to start thinking about the value of friendship that had taken root since all those years ago. Finally, every truth was uncovered and they realised that the value of friendship was something priceless. The lesson learned by these three friends taught them the meaning of appreciation, honesty dan and sharing problems among friends.

The antagonist group did not show any clear conflict among them. This group mainly brought provocation towards the protagonist group. Even though the value of friendship was not clearly shown, the existence of antagonist group was created to help develop the storyline further. Nevertheless, within the antagonist group, great value of friendship could still be seen such as the relentless support given among themselves when the three of them did not achieve the future they desired. But, moral values was adamantly instilled when one of them, Nizam, opted to donate one of his kidneys to Sherry in critical moments.

The third group was the supporting role group which consists of Aziz, Ruben and Shishi. The reason this group was introduced was to enliven the storyline. They were more natural and cheeky. Nonetheless, the communication process between them and the protagonist group was that of 
INTERNATIONAL JOURNAL OF ACADEMIC RESEARCH IN BUSINESS AND SOCIAL SCIENCES Vol. 10, No. 11, 2020, E-ISSN: 2222-6990 @ 2020 HRMARS

normal friends. Moral values that can be seen within this group's dynamics is during the second scene in which they cared about Uda who was depressed.

The combination of the value of friendship exhibited by the three different groups had further strengthened the theme of friendship, allowing it to be as one of the strengths of this musical theatre. The journey along the story took the audience to one clear message, that is for the audience to appreciate their friends as well as accepting their friends' strengths and weaknesses with all their hearts. A sincere friendship will be established by itself when the value of friendship is appreciated deeply like a gorgeous rainbow.

\section{Conclusion}

Garis-garis Pelangi shows that musical theatre is capable of functioning as a medium for conveying messages about noble values in society. Overall, this study found that in addition to the elements of music and songs in a performance, musical theatre is also a medium that functioning to show reflection of culture and custom that can be seen as an effort to uphold local culture to the world. The role of songs and lyrics gives strength to the formation of a presentation style. Musical manuscripts should be more sensitive to the importance and strength of songs and lyrics to convey the message and not only to emphasize the storyline alone. Musical strength is also influenced by the form of the song and the style of performance that capable of giving visual influence to the audience. An understanding of the concept of persuasion and reflection of society needs to be emphasized so that a work can be elevated as a source of information to a community.

This research, in general, can help in contributing the implementation of new knowledge in coordinating a musical theatre performance that has been increasingly in demand currently. The introduction to the concept of jukebox musical has also inspired the local performance arts activists to produce more appealing ideas to deliver messages through entertainment medium. Current performance arts are not only seen as a medium for entertainment, it also plays the role to educate and cultivate a better world and community.

The combination of the concept of jukebox musical in developing moral values is one of the concepts that can contribute to a better understanding towards the storyline and the characters. The use of previously recorded or famous songs do not only help to ease the process of appreciation for newcomers, but it also draws the audience closer to the performance. Attracting the audience with the songs that they often listen to is one of the methods to make sure the audience stayed glued to the performance and indirectly bringing them back to their own memories and experiences when they watch the performance if the songs hold significant meaning to them.

The development of characters through songs is also a method that can be cultivated by the technique of dialogue utterances. Appreciation assisted with melody, rythm and lyrics will give more impact to the actor, actresses and the audience, making them feel like they are watching a video clip. In conveying certain messages, the concept of jukebox musical also demands a suitable selection of songs to give emphasis on the storyline. In the context of GGP, song selection played a very important role and it functioned in delivering different messages following the characters and situations. The 
INTERNATIONAL JOURNAL OF ACADEMIC RESEARCH IN BUSINESS AND SOCIAL SCIENCES

Vol. 10, No. 11, 2020, E-ISSN: 2222-6990 @ 2020 HRMARS

value of friendship conveyed through songs and stories has also helped to instill moral values especially in true friendships.

\section{Acknowledgement}

Deep appreciation and gratification for Faculty of Music and Performing Arts, Sultan Idris Education University and several individuals involved in data contribution throughout the in completing this research.

\section{Corresponding Authors}

Muhammad Faisal bin Ahmad

Faculty of Music and Performing Arts

Sultan Idris Education University

35900 Tanjong Malim, Perak, Malaysia

Email: mfaisal@fmsp.upsi.edu.my

\section{References}

Ismail, A. (2008). Cabaran 2008 - Teater Tempatan Perlu Anjakan. Utusan Online (14/01/2008). Utusan Malaysia (M) Sdn Bhd.

http://ww1.utusan.com.my/utusan/info.asp?y=2008\&dt=0114\&pub=utusan_malaysia\&sec= sastera\&pg=sa_01.htm

Cooper, L. (1960). The Rhetoric of Aristotle. Prentice Hall.

Deer, J. (2014). Directing in Musical Theatre: An Essential Guide. New York: Routledge.

Faigin, G. (2008). The Artist's Complete Guide to Facial Expression. Watson-Guptill; 2nd Edition.

Harvard, P. (2014). Acting Through Song: Techniques and Exercises for Musical-Theatre Actors. United Kingdom: Nick Hern Books.

Kimbrough, A. M. (2002). The Sound Of Meaning: Theories Of Voice In Twentieth-Century Thought and Performance. Louisiana State University.

Kernodle, G. R. (1967). Invitation to The Theatre. Harcourt Brace and World: New York.

Luhrmann, B. (2001). Moulin Rouge!: The Splendid Book That Charts the Journey of Baz Luhrmann's Motion Picture. Newmarket Press; 1st ed edition.

McLamore, A. (2018). Musical theater : An Appreciation. Upper Saddle River, NJ Upper Saddle River, NJ.Pearson Prentice Hall

Paige, E. (2015). Musicals the Definitive Illustrated Story. London; Dorling Kindersley.

Robert L. S. (1998). Making a Friend in Youth. Aldine Transaction: Chicago.

Robiah K. Hamzah. (2012). Nilai Murni dalam Pengajaran Bahasa Melayu. Dewan Bahasa dan Pustaka. Kuala Lumpur.

Sachari, A. (2002). Estetika. Makna, Simbol dan Daya. Penerbit ITB. Bandung.

Taylor, Millie, Symonds, Dominic. (2014). Gestures of Music Theater: The performativity of Song and Dance. New York: Oxford University Press.

Woodhead, M. (2005). Early Childhood Development: a question of rights. The Open University; UK 